\title{
A Rare Case of Walled-off Pancreatic Necrosis Complicated by Splenic Artery Rupture Manifested After Surgical Internal Drainage - Diagnostic and Therapeutic Aspects
}

\author{
Valeriu Șurlin1', Dana Marinescu', Mircea Ionescu' ${ }^{2}$ Ștefan Pătrașcu', Sarmis Săndulescu', Adrian Saftoiu ${ }^{3}$, \\ Bogdan Ủngureanu ${ }^{3}$, Dan Herzog ${ }^{4}$, Ion Georgescu', D̉ragoș Mărgắritescu'
}

'Department of Surgery, Emergency County Hospital of Craiova, University of Medicine and Pharmacy, Craiova, Romania ${ }^{2}$ Department of Anesthesiology, Emergency County Hospital of Craiova, University of Medicine and Pharmacy, Craiova, Romania ${ }^{3}$ Department of Gastroenterology, Research Center of Gastroenterology and Hepatology, University of Medicine and Pharmacy, Craiova, Romania

${ }^{4}$ Department of Radiology and Medical Imagistics, Emergency County Hospital of Craiova, University of Medicine and Pharmacy, Craiova, Romania

Corresponding author:

Stefan Pătrașcu, MD

University of Medicine and Pharmacy

Petru Rareș 2, Craiova 200349 Romania

E-mail: stef.patrascu@gmail.com

\section{Rezumat}

Un caz rar de necroză izolată de pancreas complicată prin ruptura de arteră splenică apărută după derivatie internă chirurgicală - aspecte diagnostice și terapeutice

Necroza izolată de pancreas (NIP) de mari dimensiuni reprezintă o complicație binecunoscută a pancreatitei acute şi se asociază cu o morbiditate şi o mortalitate înalte. Prezentăm cazul unei complicații rare şi potențial letale a NIP - ruptura arterei splenice aproape de origine după drenaj chirurgical. Un pacient în vârstă de 44 de ani internat în Clinica noastră de chirurgie, diagnosticat cu NIP după un episod de pancreatită acută, a fost supus unei chisto-jejunoanastomoze pe ansă în Y a la Roux. În ziua a 4-a postoperator pacientul a prezentat scaune melenice, fiind efectuată o angiografie selectivă de trunchi celiac pentru suspiciunea de sângerare din NIP. La injectarea inițiala de contrast a fost observată o mică efuziune de contrast, care nu a mai fost evidențiată după injectări repetate. Intervenția a fost sistată, iar pacientul a fost pus sub observație atentă. În cea de-a 6-a zi postoperatorie sângerarea a reapărut, iar angiografia a indicat o efractie la nivelul arterei splenice. Cum pacientul a devenit instabil hemodinamic în Departamentul de Radiologie, a fost transferat de urgență în sala de operație, fiind practicată o laparotomie exploratorie cu sutura arterei splenice. Pacientul a avut o recuperare postoperatorie fără incidente, iar urmărirea la un an nu a identificat probleme specifice. 
Cuvinte cheie: necroză pancreatică, pancreatită acută, artera splenică, hemoragie gastrointestinală, embolizare arterială

\begin{abstract}
Large walled-off pancreatic necrosis (WON) is a well-known complication of severe acute pancreatitis, and it is associated with significant morbidity and mortality. This is the case report of a rare and potentially fatal complication of WON - a delayed splenic artery rupture close to its origin after surgical drainage. A 44-year old male patient admitted in our Surgical Department and diagnosed with WON evolving without infection for 6 months, after an episode of acute pancreatitis, underwent a Rouxen-Y WON-jejunostomy. In the 4th postoperative day patient presented melenic stools and a selective celiac trunk angiography was performed with the suspicion of a bleeding from the WON. At the initial injection of contrast a small leakage of contrast was observed but did not reappear despite repeated injection. The procedure was aborted, and the patient put under close observation. The $6^{\text {th }}$ postoperative day bleeding re-occurred, and the angiography indicated a breach in the splenic artery. As the patient developed hemodynamic instability in the Radiology Department he was immediately transferred into the operating room and an exploratory laparotomy with suture of the splenic artery was performed. The patient had an uneventful recovery and at one-year follow-up was without any particular problems.
\end{abstract}

Key words: pancreatic walled-off necrosis, acute pancreatitis, splenic artery, gastrointestinal hemorrhage, arterial embolization

\section{Introduction}

The mature pancreatic collection, such as pancreatic pseudocyst (PP) and walled-off pancreatic necrosis (WON), are relatively frequent complications of pancreatitis, with an incidence of up to $14 \%$ in cases of acute pancreatitis and in $41.8 \%$ of acute-on-chronic pancreatitis. (1) The revision of Atlanta classification, published in 2012 (2) has changed the definition of $\mathrm{PP}$ and (peri)pancreatic necrosis, as follows:

The PP is now considered a delayed complication of interstitial edematous pancreatitis, usually occurring more than 4 weeks since the onset of pancreatitis, morphologically defined as a peripancreatic or occasionally intrapancreatic fluid collection. The WON is defined as a mature collection of pancreatic or peripancreatic necrosis contained within a radiologically visible capsule of reactive tissue. However, many references in the literature before 2012 include these newly-defined entities under the same general term of "pancreatic pseudocyst" thus being prone to some degree of confusion $(3,4)$.

The complication spectrum ranges from rupture of the WOPN or PP in the peritoneal cavity or in a cavitary viscus, to intracystic hemorrhage by erosion of parietal blood vessels, pseudoaneurism, infection, compression on duodenum with gastric outlet obstruction or compression on portal vein with subsequent portal hypertension (5).

WOPN (and PP implicitly) can injure important nearby blood vessels, like the splenic or the gastroepiploic artery, superior mesenteric artery, by different mechanisms, such as mechanical erosion by prolonged direct pressure, or by chemical erosion due to pancreatic enzymes exposure. Acute hemorrhage can occur as a direct consequence of this chronic process, usually as a vascular fistula, or - more commonly - after the subsequent rupture of a pseudoaneurysm into the pancreatic duct (Hemosuccus pancreaticus) or a nearby cavitary organ, i.e. stomach, colon, or duodenum (6). 
We herein present the case of an exceptionally rare and potentially fatal complication of a WON, namely a splenic artery rupture manifested after the surgical internal drainage of the pseudocyst.

\section{Case Report}

This is the case of a 44 years old male patient admitted in our institution for abdominal pain and palpable epigastric tumor. Six months before the current admission the patient was hospitalized and treated conservatively in another hospital for an episode of acute severe alcoholic pancreatitis.

Except for the epigastric mass, the physical examination was quasi-normal. Laboratory data, such as hemoglobin, hematocrit, blood urea, creatinine, serum amylase and the coagulation profile, ranged between normal values. The abdominal contrast-enhanced computed tomography revealed a fluid collection with well-defined walls, at the level of the body and tail of the pancreas which was initially classified as pancreatic pseudocyst, because information about the morphologic type of acute pancreatitis was lacking - either interstitial or acute necrotizing pancreatitis (Fig. 1). Both transabdominal and endoscopic ultrasonographic evaluations indicated viscous content, the fluid collection corresponding to a WON, and the gastroenterologist who performed the procedure

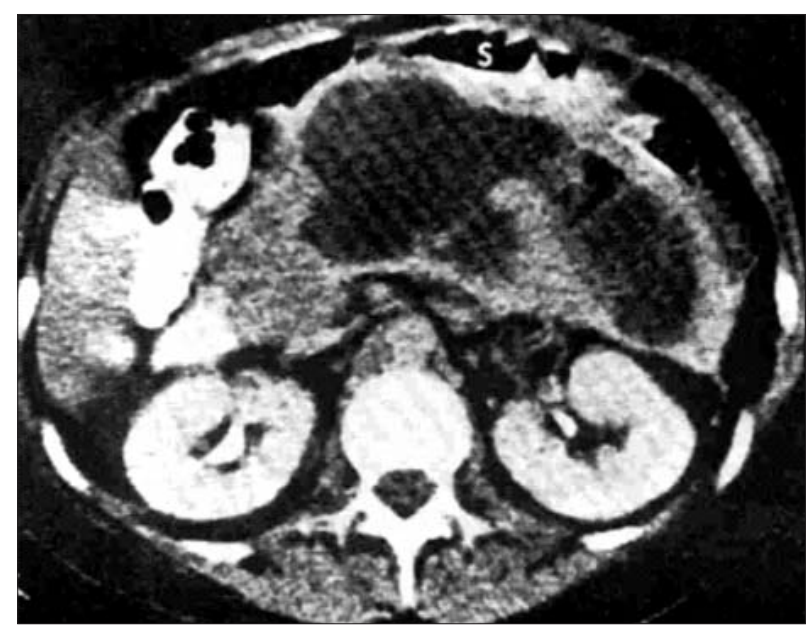

Figure 1. Contrast-enhanced computed tomography image of pancreatic walled-off necrosis (WON) at the level of the body and tail of the pancreas considered it ineligible for endoscopic internal drainage.

Decision was made to undergo open surgical procedure. A midline laparotomy offered good access. In the supramesocolic floor there were a lot of fibrosis and adherences, the gastro-colic ligament shortened and stomach in close relationship with the transverse colon, the same findings were in the area of lesser omentum, indicating a severe inflammation in the previous episode of acute pancreatitis. However, the WON was fund bulging through the transverse mesocolon, near the duodeno-jejunal angle. Opening of the collection revealed a dark green turbid fluid content with some debris. The content was evacuated, the cavity was abundantly washed with saline and a Roux-enY transmesocolic WON-jejunostomy completed the procedure.

Although the initial postoperative course was uneventful, during the 4th postoperative (p.o.) day the patient presented repeated melenic stools. We decided to perform a selective celiac trunk angiography with the suspicion of a bleeding from the WON. After catheterization of the celiac trunk the contrast injection revealed a brief and small extravasation of contrast, that did not reappear after repeated injections of contrast agent for a period of as long as at least 40 minutes. As the origin of the bleeding was not properly located and no other bleeding was identified we decided to put the patient under close observation in the surgical ward (Figs. 2, 3). The patient displayed a good general status, with no melenic stools and a hemodynamically stable condition, still he received multiple blood transfusions as hemoglobin level was below $8 \mathrm{~g} / \mathrm{dl}$.

However, the $6^{\text {th }}$ p.o. day marked a sudden re-onset of melenic stools, cold sweats and pallor. As the patient was hemodynamically stable he was immediately transported to the Radiology Department and another celiac trunk angiography was performed, revealing rupture of the splenic artery near its emergence from celiac trunk. Unfortunately, no further angiographic therapeutic measures were performed as the patient developed a hemodynamic instability, with the procedure being promptly 


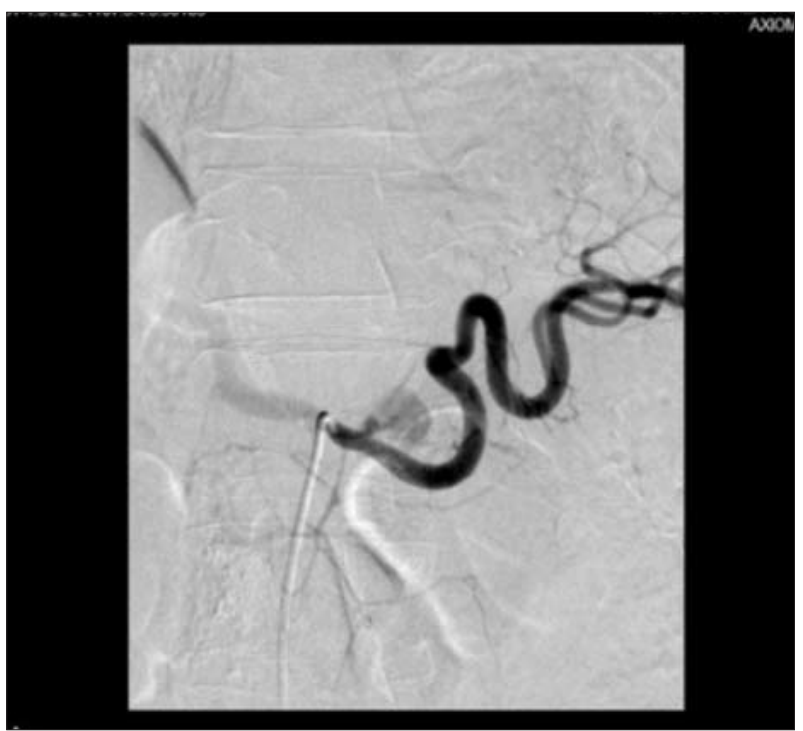

Figure 2. Selective catheterization of the celiac trunk in a patient with postoperative bleeding after cystojejunostomy for WON

aborted, and the patient requiring immediate transfer in the operating room for an emergency re-laparotomy. Access to the WON was managed difficultly because of dense adhesions, initially through the lesser omentum, and finally through the gastro-colic ligament to obtain better exposure, with difficult local dissection because of fibrosis. A major source of bleeding from splenic artery close to its origin was identified, which required cross clamping of the aorta at the level of the hiatal hiatus to reduce the flow and allow good identification of the artery and its lesion. The breach was sutured with polypropylene $5 / 0$. The spleen did not show any sign of ischemia and it was left in place. The postoperative course was uneventful, with no further bleeding, and patient was discharged in the $14^{\text {th }}$ p.o. day. The 3 months and one-year post-operative follow-up showed normal healing.

\section{Discussion}

The 2012 revision of the Atlanta Conference refined the previous classification of $\mathrm{PP}$, considering as pseudocysts only those fluid collections with amylase-rich clear content, but with minimal or no debris, occurring mainly in interstitial acute pancreatitis. This

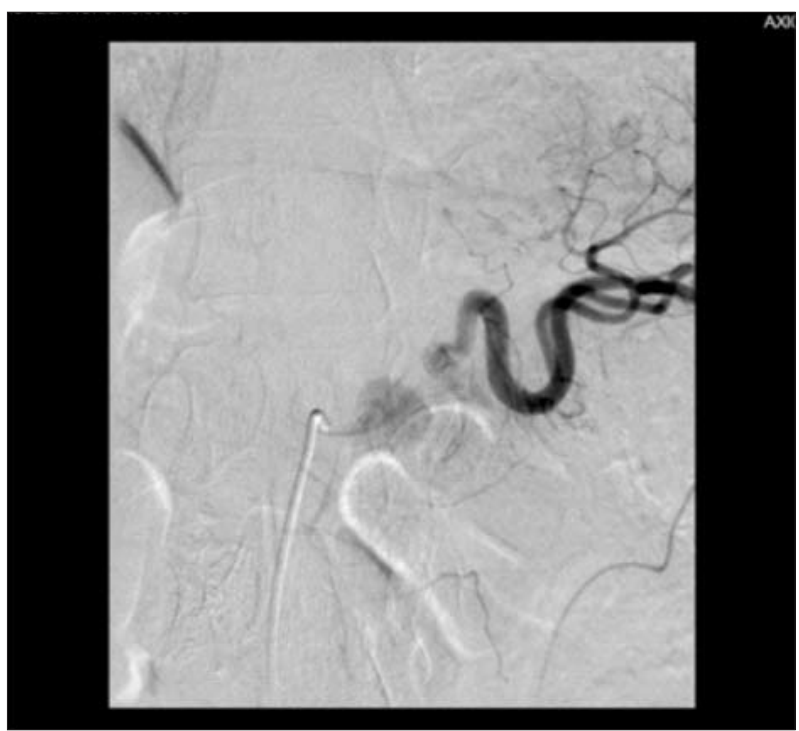

Figure 3. Bleeding near the emergence of the splenic artery in the same patient

revision introduced the term of Walled-off Pancreatic Necrosis (WON), this new pathologic entity being defined as a collection with detritus and necrotic material, occurring in necrotizing pancreatitis $(2,7)$. Previous nomenclature was inconsistent, since it referred to WON as pancreatic sequestration, organized pancreatic necrosis or pseudocyst associated with necrosis. $(8,9)$ WON originates in the necrotic pancreatic or peripancreatic tissues and, similar to PP, a pancreatic ductal communication may occasionally be encountered. The differential diagnosis can be difficult based solely on contrastenhanced computed tomography, as solid necrotic content is not readily distinguishable from fluid collections, therefore additional investigations such as endoscopic ultrasound and magnetic resonance imaging should be used (2).

The management of WON and PP range from conservative treatment, usually in case of small collections, to operative techniques for large collections (10). The armamentarium of surgical techniques consists in minimal invasive procedures, such as endoscopic or endoscopic internal drainage, to open surgery (11). Internal drainage techniques vary in efficacy, with cystogastrostomy providing a less effective drainage of the cyst compared to the anastomosis with a 
defunctionalized loop of jejunum, or even in some instances to the external drainage, especially in case of large collections (12).

In the case presented above, the aspect of the collection was more in the area of WON than pure PP, because there was some amount of debris and the content was very turbid, but at that time the paper with the revision had not been published (2).

If the management of the PP, as defined by the 2012 revision of Atlanta classification, should be successful in more than $90 \%$ of cases by endoscopic EUS guided puncture and drainage, with or without a catheter left in place, for the WON more expertise is required, and the turbidity of the content and the necrotic material require a stent (SEMS - self-expandable metallic stent) to create an endoscopic anastomosis, to allow good drainage, repeated endoscopic exploration of the cavity, debridement and lavage $(13,14)$. In those cases, surgery has higher rates of success with external drainage, that should be avoided because of risk of external pancreatic fistula, or internal drainage by cyst-gastrostomy or cyst-jejunostomy.

The particular aspects of the case consist in the rupture of the splenic artery after the surgical internal drainage of the WON. In the same time, a vascular lesion next to emergence of the splenic artery from the celiac trunk makes any procedure, especially a surgical one, difficult to perform and associating a high morbidity.

The transcatheter arterial embolization (TAE) could be considered, as it has the advantage of being minimally invasive and relatively fast. Depending on the anatomical topography of lesions, TAE can effectively be used in lesions located on gastroduodenal, pancreaticoduodenal, and intrapancreatic arterial branches (15). Some studies even indicate that the mortality rates after surgery for vascular lesions located at the head of pancreas may surpass that of the body and tail ( $43 \%$ vs $16 \%$ ), thus extending the indication of TAE for this type of pathology (16). The success rates vary between $70-100 \%$, with a re-bleeding rate of $37 \%$ and a rate of success for the second attempt of up to $68 \%$ (17). However, there is no indication for TAE in case of main splenic artery injuries, especially when the lesion is located at its origin from the celiac trunk. There are multiple reasons for this restrictive attitude, as TAE of the splenic artery makes a rather dangerous procedure, with increased risk of splenic abscess, infarction, or necrosis of the pancreas.

Other interventional radiology vascular procedures include stent grafting, which can be able to preserve the blood flow, as well as the use of side-hole catheters in tortuous vessels, for which the side holes remain in the aorta (18, 19). We consider that these procedures would be more suited in such cases than ours for all the above-mentioned reasons.

Surgery, on the other hand, is indicated for specific locations, such as vascular lesions at the level of the body and tail of the pancreas, but it may often prove to be difficult and carry a high morbidity, due to poor surgical access and local anatomical conditions determined by dense fibrotic adhesions. Moreover, the surgical attitude may vary from local hemostasis, sometimes using specific vascular surgery procedures, as in our case, to extensive, multiorgan resection surgery, which can furtherly increase the morbidity and mortality $(5,20)$.

\section{Conclusions}

Erosions of important blood vessels may present as a delayed manifestation and can occur even after evacuation and definitive treatment of a WON, such as surgical internal drainage, as in our case. Weakening of the adjacent blood vessels walls trough foregoing erosion by the pancreatic enzymes may be incriminated. Interventional angiography should be the primary choice if equipment and expertise are available, and even in case of failure the diagnostic information provided are of utmost importance to guide the surgical approach, which may also be very difficult.

\section{Conflict of interests: None}

\section{References}

1. Kim KO, Kim TN. Acute pancreatic pseudocyst: incidence, risk 
factors, and clinical outcomes. Pancreas. 2012 May:41(4):577-81.

2. Banks PA, Bollen TL, Dervenis C, Gooszen HG, Johnson CD, Sarr MG, et al. Classification of acute pancreatitis-2012: revision of the Atlanta classification and definitions by international consensus. Gut. 2013;62:102-111.

3. Nemes R, Georgescu I, Margaritescu D, Saftoiu A, Chiutu L, Georgescu E, et al. The pancreatic pseudocyst - late complication of the severe acute pancreatitis. Therapeutic options. Chirurgia (Bucur). 2006;101(3):259-65.

4. Georgescu I, Nemes R, Cârtu D, Surlin V, Margaritescu D, Dumitrescu D, et al. Severe acute pancreatitis - diagnostic and therapeutic strategy. Chirurgia (Bucur). 2005;100(6):557-62.

5. Masatsugu T, Yamaguchi K, Yokohata K, Mizumoto K, Chijiiwa K, Tanaka M. Hemorrhagic pseudocyst and pseudocyst with pseudoaneurysm successfully treated by pancreatectomy: report of three cases. J Hepatobiliary Pancreatic Surg. 2000;7(4):432-7.

6. De Vries Reilingh TS, Postma VA, Aufenacker TJ, Strobbe LJA, Rosman C. A rare cause of acute upper gastrointestinal hemorrhage. Case reports in gastroenterology. 2009:3(3):400-403.

7. Bradley EL., 3rd A clinically based classification system for acute pancreatitis. Summary of the International Symposium on Acute Pancreatitis, Atlanta, Ga, September 11 through 13, 1992. Arch Surg. 1993;128(5):586-590.

8. Yeo CJ, Sarr MG. Cystic and pseudocystic diseases of the pancreas. Current Probl Surg 1994:XXXI:165-252.

9. Hariri M, Slivka A, Carr-Locke DL, et al. Pseudocyst drainage predisposes to infection when pancreatic necrosis is unrecognized. Am J Gastroenterol 1994:8:1781-4.

10. Agalianos C, Passas I, Sideris I, Davides D, Dervenis C. Review of management options for pancreatic pseudocysts. Translational Gastroenterology and Hepatology. 2018;3:18.

11. Udeshika WAE, Herath HMMTB, Dassanayake SUB, Pahalagamage SP, Kulatunga A. A case report of giant pancreatic pseudocyst following acute pancreatitis: experience with endoscopic internal drainage. BMC Research Notes. 2018;11:262.

12. Johnson LB, Rattner DW, Warshaw AL. The effect of size of giant pancreatic pseudocysts on the outcome of internal drainage procedures. Surg Gynecol Obstet. 1991 Sep; 173(3):171-4.

13. Arvanitakis M, Dumonceau JM, Albert J, Badaoui A, Bali MA, Barthet $\mathrm{M}$, et al. Endoscopic management of acute necrotizing pancreatitis: European Society of Gastrointestinal Endoscopy (ESGE) evidence-based multidisciplinary guidelines. Endoscopy. 2018 May;50(5):524-546.

14. Braden B, Koutsoumpas A, Silva MA, Soonawalla Z, Dietrich CF. Endoscopic ultrasound-guided drainage of pancreatic walled-off necrosis using self-expanding metal stents without fluoroscopy. World J Gastrointest Endosc 2018; 10(5): 93-98.

15. Stösslein F, Zimmermann L, Bulang T. Embolization treatment of bleeding complications in pancreatitis. J Hepatobiliary Pancreat Surg. 1998;5(3):344-7.

16. Marshall GT, Howell DA, Hansen BL, Amberson SM, Abourjaily GS, Bredenberg CE. Multidisciplinary Approach to Pseudoaneurysms Complicating Pancreatic PseudocystsImpact of Pretreatment Diagnosis. Arch Surg. 1996;131(3):278-283.

17. Golzarian J, Nicaise N, Devière J, Ghysels M, Wery D, Dussaussois L, et al. Transcatheter embolization of pseudoaneurysms complicating pancreatitis. Cardiovasc Intervent Radiol. 1997;20(6):435-40.

18. Lee HG, Heo JS, Choi SH, Choi DW. Management of bleeding from pseudoaneurysms following pancreaticoduodenectomy. World J Gastroenterol. 2010;16(10):1239-1244.

19. Mauri G, Mattiuz C, Sconfienza LM, Pedicini V, Poretti D, Melchiorre $\mathrm{F}$, et al. Role of interventional radiology in the management of complications after pancreatic surgery: a pictorial review. Insights into Imaging. 2015;6(2):231-239.

20. Zhao J, Kong $X$, Cao D, Jiang L. Hematochezia from splenic arterial pseudoaneurysm ruptured into pancreatic pseudocyst coexisting with fistula to the colon: a case report and literature review. Gastroenterology Research. 2014;7(2):73-77. 